\title{
Chapter 7 \\ Urban Wetlands and Riparian Forests as a Nature-Based Solution for Climate Change Adaptation in Cities and Their Surroundings
}

\section{Dagmar Haase}

\begin{abstract}
Wetlands and riparian forests belong to the most productive, but also the most vulnerable, ecosystems in urban regions and cities due to their complex watershed system, often very high biodiversity and the pressure from urban land use and surface sealing. Wetlands and floodplain forests are often highly valued recreational areas, providing many benefits for urban dwellers, such as fresh air, moisture, oxygen and biogenic essentials as well as many cultural and place-based values. Wetlands and riparian forests are very efficient spaces for water and matter regulation, pollutants fixation and flood water retention. Thus, particularly for dense urban areas, they represent almost perfect nature-based solutions for risk mitigation and adaptation concerning both climate extremes: flood and drought. Moreover, they can serve as a buffer against high air temperatures and provide wetness during heat waves. However, urban wetlands and riparian forests are often endangered by urbanisation pressure, land take for construction purposes and pollution. This chapter provides arguments that urban wetlands being a nature-based solution for cities facing climate change and presents design options to expand and even create such wetlands in cities where remnants are no longer available.
\end{abstract}

Keywords Urban wetlands • Riparian forests $\bullet$ Nature-based solution $\bullet$ Climate change adaptation $\bullet$ Cities

\footnotetext{
D. Haase $(\triangle)$

Department of Geography, Humboldt University Berlin, Berlin, Germany

Department of Computational Landscape Ecology, Helmholtz Centre for Environmental

Research - UFZ, Leipzig, Germany

e-mail: dagmar.haase@geo.hu-berlin.de
} 


\subsection{Introduction: What Is the Value of Wetlands and Riparian Forests in Cities?}

Wetlands and riparian forests belong to the most complex ecosystems on the planet. Their water balance and watershed systems are highly complex in terms of the ongoing interactions between ground-, interflow and surface waters (Haase and Nuissl 2007). Wetlands are able to store an enormous amount of water in their sediments, soils and vegetation. They can buffer extreme air temperatures due to the flows of evapotranspiration they create. Their typically loamy, clay and silt-rich floodplain soils are fantastic buffers and transmitters of all kinds of organic and inorganic pollutants emitted; they represent a kind of 'translocation area' for matter and are a sink and source of pollutants at the same time. Mature floodplain trees sequester and store considerable amounts of $\mathrm{CO}_{2}$, contributing to climate change mitigation. In terms of flora and fauna, wetlands and riparian forests provide multiple wet and perennial habitats and, consequently, are home to thousands of species (Fig. 7.1).

Since the industrial revolution and in particular since WW II, cities represent the main 'habitat' for humans, with about $55 \%$ of the world population and current estimates assume that some $75 \%$ of the global population will live in cities by 2030 (UN 2016). Cities are places of close contact between humans and nature, where society and biodiversity are privy to complex interactions and co-evolution in terms of typical urban niches adapted gene mutation and species creation (Alberti 2015).

Many cities have been established along rivers due to the economically and defenserelated strategic location and the availability of water resources and fertile soils (Kühn and Klotz 2006). Thus, wetlands, riparian forests and cities already share a long history punctuated with synergistic interactions and risk creation (Schanze 2006). More specifically, river floods endanger humans and their properties and humans in turn destroy wetlands and floodplain forests by means of construction, surface sealing, groundwater regulation and tree cuttings. However, when society supports the proper functioning of wetlands, these habitats and their forests can produce significant ecosystem services for urban dwellers, including the aforementioned regulation functions as well as being recreational areas and places for all age groups to experience and

Leipzig, Weiße-Elster-floodplains

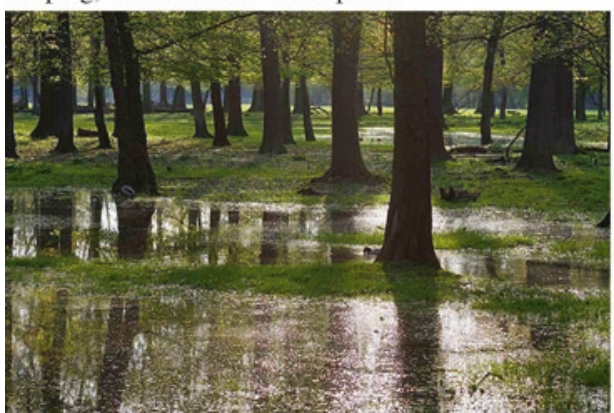

Vienna, Danube floodplains

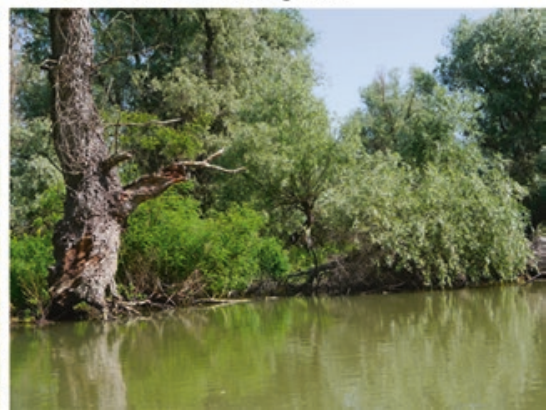

Fig. 7.1 Typical urban wetland and associated floodplain forest in Leipzig, Germany, and Vienna, Austria (Photos: Dagmar Haase) 
enjoy nature and, what is more, providing cool places during hot summers and thus to support physical health of urban dwellers (Haase 2003; Andersson et al. 2015).

As outlined previously, wetlands and riparian forests offer a multitude of services which benefit both society and biodiversity. They are ideal nature-based solutions for regulating the effects of climate stress and climate change that cities are increasingly faced with, including heat waves, long dry spells, floods and related accumulation of polluted sediments. Furthermore, and in addition to their importance in water flow regulation, they are stepping stones for species of different taxa and place of the creation of novel or altered habitats and the survival of endangered species (Elmqvist et al. 2015).

However, and not least because of the aforementioned properties, river regulation and drainage of wetlands have been common practice in most areas of Europe for centuries, with interventions increasing over the past 50-100 years. More than $50 \%$ of the European wetlands that existed 100 years ago have been lost mainly to urban developments (conversion into other land types) (European Commission 1995), leading to a substantial decrease in the number, size and natural habitat of large bogs and marshes and small or shallow lakes. As a result, both European legislation (e.g. the EU Birds Directive (1979) and the EU Flora, Fauna and Habitats Directive (1992; European Commission) and international agreements (i.e. the Convention on Wetlands of International Importance especially as Waterflow Habitat (Ramsar, Iran, 1971)) have implemented protective measures. A considerable part of European wetlands $\left(>40,000 \mathrm{~km}^{2}\right.$ or about $\left.0.5 \%\right)$ has been designated as 'Ramsar sites' under the international convention.

Next to cities themselves, roads have a major impact on wetlands and riparian areas in central parts of Europe characterised by a dense infrastructure, such as Austria, Belgium, Denmark, Germany, Luxembourg and the Netherlands. And, what is more, this pressure along with peri-urbanisation is expected to increase as settlement areas and transport networks expand (Fig. 7.2).

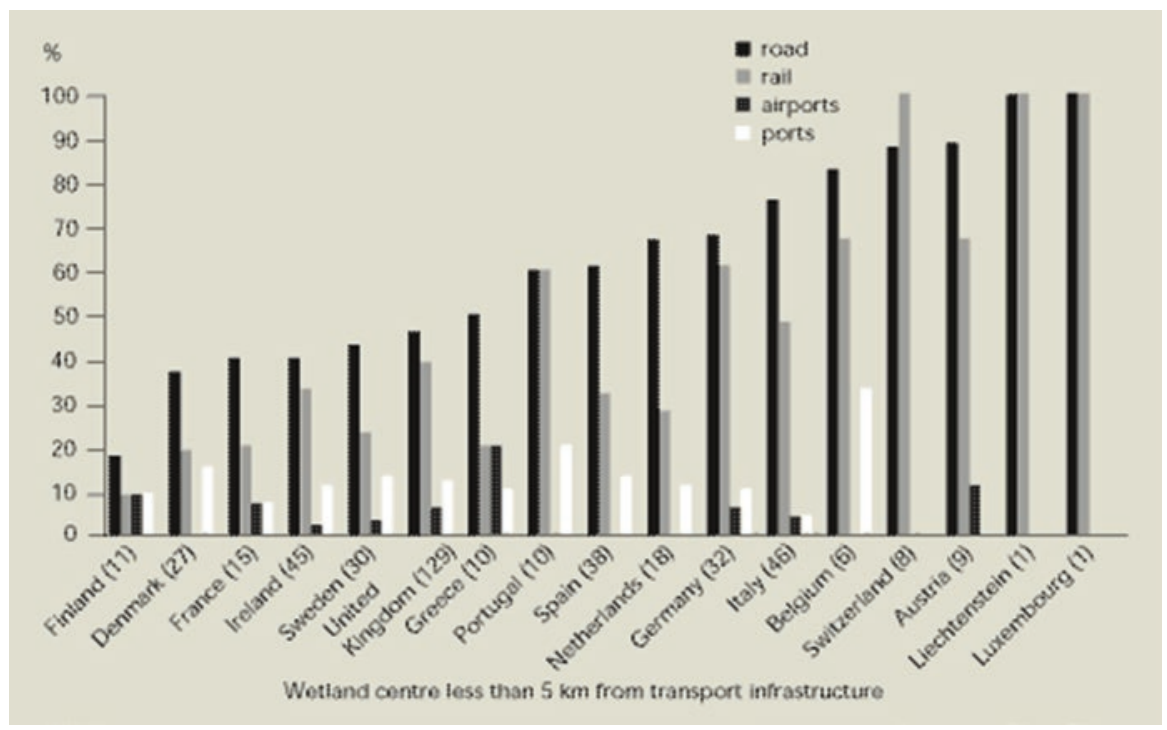

Fig. 7.2 Proximity of major transport infrastructure to Ramsar areas in selected European countries (European Commission 1995) 


\subsection{Ecosystem Services Relevant for Climate Change Adaptation Provided by Wetlands and Riparian Forests and Trade-Offs}

Wetlands and riparian forests provide a multitude of ecosystem services (Haase 2014; Kroll et al. 2012). They are extremely efficient and important cooling elements in urbanised areas due to their continuous high groundwater levels, their wet soils and, in the event that they include a forest stand, the leaf-based shading and transpiration effects (Breuste et al. 2013). Concerning climate change adaptation, the suitability of wetlands is manifold ranging from their organic soils as carbon stores to its alluvial parts as areas for local climate cooling, what is more, the role of floodplains as means to slow down flood peaks, as space for water and allowing for floods to happen and for water storage to counteract droughts.

In Europe, almost all riparian or floodplain forests are broadleaf forests with originally unique but heavily modified, except a few situations, tree stands and forest habitats. Natural floodplain tree stands with large, green leaves which help to cool the surroundings more efficiently than typical park trees (Table 7.1; Haase and Gläser 2009; Elmqvist et al. 2015). Data from Manchester (UK) show, for example, that a $10 \%$ increase in tree canopy cover may result in a $3-4{ }^{\circ} \mathrm{C}$ decrease in ambient temperature (Gill et al. 2007) and save large amounts of energy used in air conditioning (Nicolson-Lord 2003; Akbari 2002).

Due to increasing car traffic and travel activities in most of the large and megacities worldwide, air pollution with particular matter $\left(\mathrm{PM}_{10}, \mathrm{PM}_{2.5}\right.$ and $\left.\mathrm{PM}_{<1}\right)$, $\mathrm{NO}_{\mathrm{x}}$ and ozone, has been considerably increasing in the last three decades since 1990 (Weber et al. 2014a, b). This pollution heavily and considerably impacts the respiratory and cardiovascular systems of urban populations. Consequently, the health thresholds are exceeded in many cases, which have led to transport regulations and limits such as no driving in city centres or higher standards for cars in the cities in cities like Delhi or Karachi as well as in Milan, Torino, Stuttgart and Sarajevo. Trees are efficient filters of such particular air pollution, although they cannot mitigate the whole of the pollution concentration (Baró et al. 2015). The results of a multiple-city study indicate that the average air quality improvements due to air purification supply by trees are relatively low at the city scale, e.g. nitrogen oxides, particulate matter or ozone varying, e.g. from $0.07 \%$ in Rotterdam to

Table 7.1 Leaf area index (LAI) of floodplain forest species and wetland lawns (in italic letters) compared to 'classical' urban tree species and grassland (defined as leaf area per soil unit, BFI = A(leaf)/A(soil unit)

\begin{tabular}{l|l}
\hline Tree species & BFI \\
\hline Beech & $6-8$ \\
\hline Oak & $5-7$ \\
\hline European larch & $2-4$ \\
\hline Forest pine & $3-4$ \\
\hline Spruce & $5-10$ \\
\hline Lawn & 7 \\
\hline Grassland & $1-2$ \\
\hline
\end{tabular}


$0.81 \%$ in Stockholm for $\mathrm{NO}_{2}$ ), although positive effects are likely to be more relevant in highly tree-covered areas such as urban forests; for example, the expected air improvements are higher than $6 \%$ for $\mathrm{PM}_{10}$ in Stockholm (Sweden) and Salzburg (Austria), assuming a 100\% tree cover (Baró et al. 2015). For the city of Leipzig (Germany), the whole tree cover including the floodplain forests and the street and park trees is able to balance the $\mathrm{CO}_{2}$ emissions of 6000 residents, which is about $1.5 \%$ of the urban population (Strohbach and Haase 2012).

Wetlands are also a sink for matter and could become, depending on the geochemical milieu and flooding, a source of matter (Haase and Neumeister 2001). Fluvisols, the typical soil type of wetlands, are able to bind many organic and inorganic compounds due to their high contents of fine grain material (clay, silt), Fe oxides and, in their topsoils, up to $10 \%$ organic carbon (Table 7.2; Haase and Neumeister 2001). Thus, a closed coverage layer of wetland soils is the best protection against the pollution of the local and regional aquifers that provide fresh water for urban dwellers (Haase 2009). Thus, the soils and tree cover of wetlands and floodplains serve as a highly efficient metabolic body for nutrient fluxes and pollutant, benefiting the humans settling around these areas.

Next to the many abiotic properties and processes that are beneficiary for humans, wetlands and riparian forests provide excellent and unique habitats for not only humans but also many other species (Elmqvist et al. 2015). Floodplain forest trees such as Quercus (oak) or Fraxinus (ash) as well as Salix (willow) or Carpinus (beech) are habitat to up to 1000 animal species and thus critical elements of local and regional food chains. Whole food webs/chains are linked through particularly old floodplain forest trees with mighty stems and thick bark, and wetlands are larger landscape elements that link habitats at the regional scale as fauna migration and nesting areas (Alberti 2015). Due to the high variety of species that inhabit wetlands, these landscapes are specifically robust against single pests and thus act as natural pest control (Alberti 2015) as the survival rate of the ecosystem is higher when not all species are affected. At the same time, being wet habitats and charac-

Table 7.2 Matter sink and matter flow balancing functions of fluvisols compared to other urban substrates

\begin{tabular}{l|l|l|l|l|l}
\hline Soil/substrate property & Fluvisol & $\begin{array}{l}\text { Regosol } \\
\text { (sand) }\end{array}$ & Cambiosol & $\begin{array}{l}\text { Gleysol } \\
\text { (clay) }\end{array}$ & $\begin{array}{l}\text { Regosol } \\
\text { (sand) }\end{array}$ \\
\hline Infiltration capacity & + & ++ & \pm & -- & ++ \\
\hline Nutrient accumulation & + & -- & - & ++ & -- \\
\hline Nutrient cycling & ++ & - & + & + & - \\
\hline Pollutant accumulation & ++ & - & + & ++ & - \\
\hline Water capacity & ++ & -- & + & ++ & -- \\
\hline Water flow balancing & + & - & ++ & - & - \\
\hline Mechanical filtering & + & + & ++ & - & + \\
\hline Chemical filtering & + & -- & - & ++ & -- \\
\hline Drainage & \pm & ++ & -- & - & ++ \\
\hline Erosion susceptibility & - & \pm & + & -- & \pm \\
\hline
\end{tabular}

with ++ is very good/high, + is good (high), \pm is medium, - is poor/low and -- is very poor/low 
terised by closeness to water, they provide ideal breeding grounds for the spread of invasive species such as the tsetse fly, Aedes aegypti or Amenophelis that inflow from south and are carrier of so far unknown illnesses such as yellow or dengue fever or types of ticks bringing meningitis and encephalitis as well as bringing endemic malaria possibly back to Europe (Medlock and Leach 2015). Thus, while using wetlands as a nature-based solution to flood alleviation, air cooling and pollutant fixers to address those threats, they can also create trade-offs and disservices (Döhren and Haase 2015).

Potentially the most important and widely known property of wetlands and floodplain forests are their role as a flood moderator; their function as drought moderator is far less known (Haase 2011). Wetlands and floodplains are spaces to naturally store and 'save' water in times of high rainfall and long periods of precipitation. Historical wetland management has made use of the high water storage and spatial inundation capacities of floodplains and thus created the most fertile and productive landscapes in former centuries, such as the Hungarian Tisza floodplains (Haase 2011), the Oder valley in Germany (Dalchow and Bork 1998) or the area of Kaliningrad in Northwestern Russia. Only in case they were object of an artificial embankment and river regulation, wetlands can change from places of saving water to places that let water easily migrate into surrounding spaces creating loss of life, loss of property and loss of assets being a clear trade-off (Scheuer et al. 2012).

\subsection{Urban Wetlands as a Nature-Based Solution and Options for Their Design}

As discussed in the previous sections, wetlands and their riparian or floodplain forests as such are solutions created by nature to store, distribute and hold water in ecosystems and whole landscapes. This function has been largely impacted by humans, mainly in cities and urban areas to use the water as resource and the river as transportation means, on the one hand, and to protect human lives and assets from floods on the other hand (see Haase 2011, Kubal et al. 2009 and Meyer et al. 2009). However, the last big floods in Europe (Elbe, Oder, Mulde, Tisza, Rhine to list a few) drew attention to the fact that technical or built protection against water will not provide $100 \%$ protection to people in cities against floods, particularly when taking climate change and longer heavy precipitation events into consideration. Moreover, events such as the hurricane Katrina in the USA in 2005 or the last Elbe flood in Germany in 2013 with hazardous bursting of large dams made very clear that technological solutions in case they fail can produce enormous damage and casualties as their capacities are enormous in terms of how much water they can collect/hinder to flow, actually much more than any nature-based solution can (see also a global map by Scheuer et al. 2012).

But, which efforts could instead be reinvested in restoring and maintaining the functionality of wetlands/floodplains? The revitalisation of large and smaller rivers 
and thus a continuous and more natural inflow and distribution of rainfall water in a larger area have been shown to improve protection against horrible flood events along rivers and coasts (Fig. 7.3; Middelkoop et al. 2004; Krysanova et al. 2008). A restoration of the (remnant) riparian vegetation would assist in reconnecting rivers with floodplains and to provide greater instream ecosystem complexity, particularly in urban areas (see examples in Fig. 7.3). In addition to restoration, wetlands could also be created, including so-called balancing ponds, and thus natural functions created by a kind of nature mimicry in the surroundings of cities. Also bioswales as their smaller version could be created along streets in, e.g. housing areas to take up and hold rainfall water and, what is more, moisturize the dry urban air after the rainfall event for a while (Fig. 7.3; Haase 2016). Also permeable surfaces can support this moistening of urban areas. A high channel diversity in the wetlands themselves but also in form of bioswales and integrated into the street network would reduce the speed of (superficial) flood transmission. All these measures are known in hydrology and hydrological construction; however, in urban planning they need better introduction and a cooperation between landscape planners, ecologists, green infrastructure specialists on the one hand and hydraulic engineers on the other to

Recreation areas to promote health and happiness

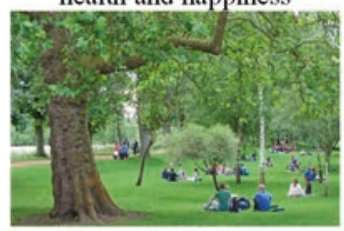

Revitalization of wetlands/rivers to balance the urban water cycle

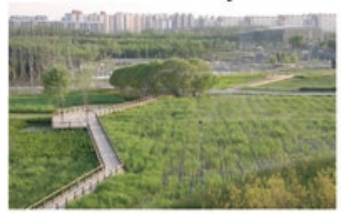

Restoring fluvisols to bind and immobilize pollutants

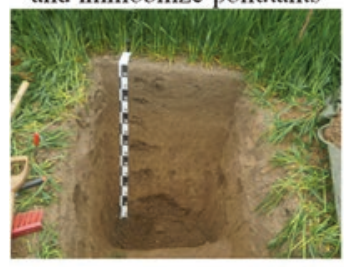

Tree planting to clean the air and to filter pollutants

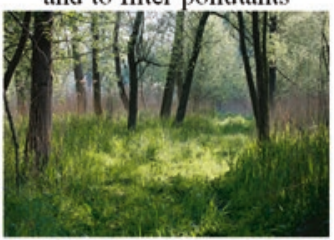

Bioswales to store rainwater in streets and to lower the flood risk

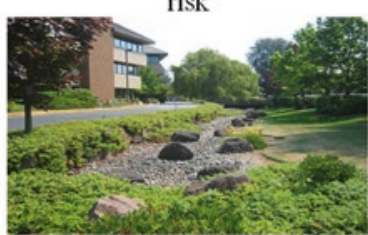

Room for rivers to alleviate floods and to safe cities from hazards

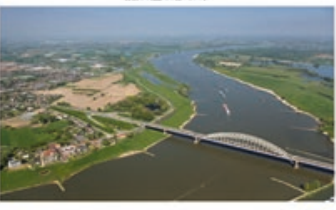

(Re-)Greening waters to buffer noise and to filter pollutants

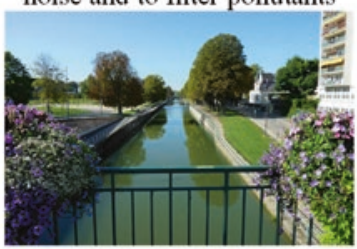

Constructed wetlands to regulate ground- and surface water flows

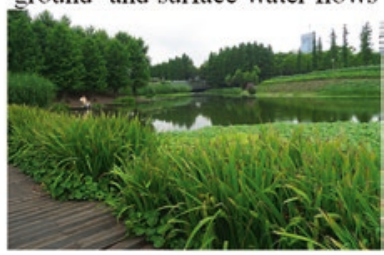

Nutrient-cycling for food production in cities and prevent food

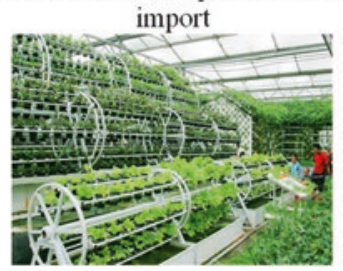

Fig. 7.3 Nature-based solutions linked to wetlands, riparian forests and floodplains (Photos: Dagmar Haase) 
Table 7.3 Nature-based and artificial/built water retention and climate change adaptation measures for relevant spatial response units

\begin{tabular}{l|l|l}
\hline Spatial response unit & Grey measures & Green measures \\
\hline \multirow{2}{*}{ Cities } & Infiltration devices & Filter strips and bioswales \\
\cline { 2 - 3 } & Dams, dikes & Permeable surfaces and filter drains \\
\cline { 2 - 3 } & Walls & Green roofs and green walls \\
\cline { 2 - 3 } & $\begin{array}{l}\text { Underground } \\
\text { drainage }\end{array}$ & Wetland restoration/construction \\
\hline Urban regions & Basins and ponds & Floodplain restoration \\
\cline { 2 - 3 } & Dams, dikes & Re-meandering \\
\cline { 2 - 3 } & Reservoirs & Restoration of lakes \\
\cline { 2 - 3 } & $\begin{array}{l}\text { Natural bank stabilisation } \\
\text { (also at catchment level) }\end{array}$ \\
\hline \multirow{2}{*}{$\begin{array}{l}\text { carger river } \\
\text { catchments }\end{array}$} & $\begin{array}{l}\text { Afforestation and forest protection } \\
\text { systems }\end{array}$ & Rand dike \\
\cline { 2 - 3 } & Reservoirs & Afforestation of agricultural land \\
\hline & & Afforestation of unused land and pastures \\
\hline & Buffer stripes of agricultural fields \\
\hline
\end{tabular}

According to Vanneuville and Werner (2012), modified

make the suggested nature-based solutions effective and successful (as already mentioned by Pahl-Wostl 2007).

The restoration and construction of wetlands would increase and enhance all of the aforementioned ecosystem services provided by wetlands and riparian forests and provide additional health benefits for urban dwellers such as cooling by tree shade, aesthetic improvement of biodiversity and healthy forest products to be foraged (e.g. fruits, mushrooms, herbs). In terms of the spatial configuration of wetlands as parts of larger river catchments, the aforementioned measures might be carried out either within cities or also upstream to be most efficient for flood protection, for example. This is a typical case for regional planning. Table 7.3 summarises again the various options of grey and green solutions in wetlands to face the effects of climate change.

\subsection{Discussion and Conclusions}

Several options have been outlined which utilise wetland and riparian forests' functionality as nature-based solutions to better face the consequences of climate change in cities and urban regions. The following are the key observations:

1. Wetlands, floodplains and riparian forests are very precious and in many respects unique ecosystems of high complexity that are able to 'deal' with large amounts of water in a spatio-temporal distribution scheme (uptake, storage, release) that 
saves humans, their assets and whole cities from extreme flooding. They have to be kept, and in case of their destruction, they have to be restored whenever economic and social trade-offs permit it. Moreover, rivers should be-as far as possible and at locations where possible-reconnected with floodplains to enhance natural water storage in the whole catchment system.

2. Wetlands can provide inspiration for how water storage could work also for nonlowland situations such as top hill situations and inner city areas. Wetlands could be created/constructed as a kind of nature mimicry in the form of constructed wetlands in the peri-urban landscape and smaller bioswales along streets in densely built inner city locations as 'smart and space saving' accepting the basic structure of the grey environment. Together, natural and newly created/constructed wetlands could support the regulation of the magnitude and timing of water runoff and flooding as well as the recharging of aquifers.

3. We need to better understand and make use of the enormous balancing, buffering and metabolic capacities of wetlands and their forests in cities as well as the recreational opportunities and air pollution filtering capacities, as they cannot simply be replaced by technology or grey infrastructure solutions.

4. As cities have been built and transformed over centuries and as humans are the dominating creative factor in cities and urban regions, natural remnants of wetlands and floodplain forests have to be combined with technological/technical solution such as discussed under (2). Implementing wetland functionality, be it restoration or creation, can be a way and a new job creator to realise 'miniwetlands' and 'riparian trenches' in areas disconnected from the river. The complementarity of both nature and technology under the supervision of society might be a clever, pragmatic but at the same time innovative solution to complex problems created by man and nature response.

5. A combination of ' $\mathrm{C} \& \mathrm{C}$ ' - conservation and construction - might be a coupled solution for most of our cities when it is about climate change adaptation. Along with this, a new way of urban governance including co-development and coproduction to create real societal benefits and acceptance is needed to give this new ' $C \& C$ ' a real chance.

However, as also discussed in this short contribution, wetlands as natural systems create trade-offs when it comes to human health and infectious diseases, particularly vector-borne diseases and regarding the loss of land for new developments. Knowledge about this fact or 'disservice' is a first step to create awareness. Strategies for public protection and, if needed, intervention are following steps to balance these trade-offs. Climate change itself can increase the 'danger' of new vectors and new infection risks, no doubt, but such trade-offs do not diminish the high value of wetlands and their riparian forests as natural solutions for adapting to climate change in cities and urban regions. For many cities across Europe, climate change and a gradual warming are already a reality, and based on recent temperature prognoses (IPCC 2016), the situation gets worse in terms of an increase in mean summer day and night temperatures and more heavy and less effective rainfall events. Thus, and despite a potential increase of vectors, there is a need to 'switch tactics' replacing grey for green. 
Investing in restoring, protecting and enhancing ecological functionality and ecosystem services in urban wetlands is not only ecologically and socially desirable (cf. Elmqvist et al. 2015), but as the contribution has shown, wetlands are socioecologically viable recognising their multiple services and all their associated benefits for the large number of beneficiaries in cities.

\section{References}

Akbari $\mathrm{H}$ (2002) Shade trees reduce building energy use and $\mathrm{CO}_{2}$ emissions from power plants. Environ Pollut 116(1):119-126

Alberti M (2015) The effects of urban patterns on ecosystem function. Int Reg Sci Rev 28(2):168192. doi: $10.1177 / 0160017605275160$

Andersson E, McPherson T, Kremer P, Frantzeskaki N, Gomez-Baggethun E, Haase D, Tuvendal M, Wurster D (2015) Scale and context dependence of ecosystem service providing units. Ecosyst Serv 12:157-164

Baró F, Haase D, Gómez-Baggethun E, Frantzeskaki N (2015) Mismatches between ecosystem services supply and demand in urban areas: A quantitative assessment in five European cities. Ecol Indic 55:146-158

Breuste J, Haase D, Elmquist T (2013) Urban landscapes and ecosystem services. In: Sandhu H, Wratten S, Cullen R, Costanza R (eds) Ecosystem services in agricultural amd urban landscapes. Wiley, Chichester, pp 83-104

Dalchow C, Bork HR (1998) Das Oderbruch - Einführung in die Entstehungsgeschichte. In: Darkow G, Bork HR (eds) Die Bewirtschaftung von Niederungsgebieten in Vergangenheit und Gegenwart, ZALF-Bericht 34. ZALF, Müncheberg, pp 13-18

Döhren P, Haase D (2015) Ecosystem disservices research: a review of the state of the art with a focus on cities. Ecol Indic 52:490-497

Elmqvist T, Setälä H, Handel SN, van der Ploeg S, Aronson J, Blignaut JN, Gómez-Baggethun E, Nowak DJ, Kronenberg J, de Groot R (2015) Benefits of restoring ecosystem services in urban areas. Curr Opin Environ Sustain 14:101-108

European Commission (1995) Commission's communication to the Council and the Parliament: wise use and conservation of wetlands. European Commission, Brussels

Gill SE, Handley JF, Ennos AR, Pauleit S (2007) Adapting cities for climate change: the role of the green infrastructure. Built Environ 33:115-133

Haase D (2003) Holocene floodplains and their distribution in urban areas - functionality indicators for their retention potentials. Landsc Urban Plan 66:5-18

Haase D (2009) Effects of urbanisation on the water balance - a long-term trajectory. Environ Impact Assess Rev 29:211-219

Haase D (2011) Participatory modelling of vulnerability and adaptive capacity in flood risk management. Nat Hazards 67:77. doi:10.1007/s11069-010-9704-5

Haase D (2014) The nature of urban land use and why it is a special case. In: Seto K, Reenberg A (eds) Rethinking global land use in an urban era. Strüngmann Forum Reports, vol 14, Julia Lupp, series editor. MIT Press, Cambridge, MA

Haase D (2015) Reflections about blue ecosystem services in cities. Sustainability Water Qual Ecol 5:77. Available online http://www.sciencedirect.com/science/article/pii/S2212613915000112

Haase D, Gläser J (2009) Determinants of floodplain forest development illustrated by the example of the floodplain forest in the District of Leipzig. For Ecol Manag 258:887-894. doi:10.1016/j. foreco.2009.03.025

Haase D, Neumeister H (2001) Anthropogenic impact on fluvisols in German floodplains. Ecological processes in soils and methods of investigation. Int Agrophys 15(1):19-26

Haase D, Nuissl H (2007) Does urban sprawl drive changes in the water balance and policy? The case of Leipzig (Germany) 1870-2003. Landsc Urban Plan 80:1-13 
IPCC (2016) http://www.ipcc.ch

Kroll F, Müller F, Haase D, Fohrer N (2012) Rural-urban gradient analysis of ecosystem services supply and demand dynamics. Land Use Policy 29(3):521-535. doi:10.1016/j.landusepol.2011.07.008

Krysanova V, Buiteveld H, Haase D, Hattermann FF, Van Niekerk K, Roest K, Martínez-Santos P, Schlüter M (2008) Practices and lessons learned in coping with climatic hazards at the riverbasin scale: floods and droughts. Ecol Soc 13(2): 32. [online] URL: http://www.ecologyandsociety.org/vol13/iss2/art32/

Kubal T, Haase D, Meyer V, Scheuer S (2009) Integrated urban flood risk assessment - transplanting a multicriteria approach developed for a river basin to a city. Nat Hazards Earth Syst Sci 9:1881-1895

Kühn I, Klotz S (2006) Urbanisation and homogenization - comparing the floras of urban and rural areas in Germany. Biol Conserv 127:292-300

Medlock JM, Leach SA (2015) Effect of climate change on vector-borne disease risk in the UK. Lancet Infect Dis 15(6):721-730

Meyer V, Scheuer S, Haase D (2009) A multi-criteria approach for flood risk mapping exemplified at the Mulde river, Germany. Nat Hazards 48:17-39. doi:10.1007/s11069-008-9244-4

Middelkoop H, van Asselt MBA, van't Klooster SA, van Deursen WPA, Kwadijk JCJ, Buiteveld H (2004) Perspectives on flood management in the Rhine and Meuse Rivers. River Res Appl 20:327-342

Nicholson-Lord D (2003) Green cities: and why we need them. New Economics Foundation, London

Pahl-Wostl C (2007) Transition towards adaptive management of water facing climate and global change. Water Resour Manag 21(1):49-62

Schanze J (2006) Flood risk management—a basic framework. In: Schanze J, Zeman E, Marsalek J (eds) Flood risk management-hazards, vulnerability and mitigation measures. Springer, New York, pp 149-167

Scheuer S, Haase D, Meyer V (2012) Spatial explicit multi-criteria flood risk - fundamentals and semantics of multicriteria flood risk assessment. In: Wong TSW (ed) Flood risk and flood management. Nova Science Publishers Inc, Hauppauge

Strohbach MW, Haase D (2012) Estimating the carbon stock of a city: a study from Leipzig, Germany. Landsc Urban Plan 104:95-104. doi:10.1016/j.landurbplan.2011.10.001

United Nations (2016) http://www.un.org/en/development/desa/population/

Vanneuville W, Werner B (2012) Water resources in Europe in the context of vulnerability. EEA 2012 state of water assessment, EEA Report No 11/2012. Office for Official Publications of the European Communities, Copenhagen

Weber N, Haase D, Franck U (2014a) Assessing traffic-induced noise and air pollution in urban structures using the concept of landscape metrics. Landsc Urban Plan 125:105-116

Weber N, Haase D, Franck U (2014b) Zooming into the urban heat island: how do urban built and green structures influence earth surface temperatures in the city? Sci Total Environ 496:289-298

Open Access This chapter is licensed under the terms of the Creative Commons Attribution 4.0 International License (http://creativecommons.org/licenses/by/4.0/), which permits use, sharing, adaptation, distribution and reproduction in any medium or format, as long as you give appropriate credit to the original author(s) and the source, provide a link to the Creative Commons license and indicate if changes were made.

The images or other third party material in this chapter are included in the chapter's Creative Commons license, unless indicated otherwise in a credit line to the material. If material is not included in the chapter's Creative Commons license and your intended use is not permitted by statutory regulation or exceeds the permitted use, you will need to obtain permission directly from the copyright holder.

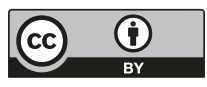

